P. H. Plieshkov, Cand. Sc. (Tech.), Prof., orcid.org/0000-0003-2141-4811, V.V.Zinzura, Cand. Sc. (Tech.), orcid.org/0000-0001-6357-064X, S.P. Plieshkov, Cand. Sc. (Tech.), orcid.org/0000-0002-3120-5397
Central Ukrainian National Technical University. Kropyvnytskyi, Ukraine, e-mail: vasiliyzinzura@gmail.com

\title{
AUTOMATIC CONTROL OF ELECTRICAL DISTRIBUTION NETWORK MODE WITH THE VOLTAGE UNBALANCE
}

Purpose. Enhancement of the efficiency of the electrical distribution networks with rated voltage of up to $1 \mathrm{kV}$ by improving automatic control systems for the parameters of the mode of electrical distribution networks with symmetrical compensating devices under conditions of voltages unbalance.

Methodology. Multicriterion optimization methods were used in solving the problem of controlling the parameters of the mode of electrical distribution networks. The Nelder-Mead numerical optimization method was used to find the final solution of the problem of multicriteria optimization. Using the methods of computer simulation, the efficiency of the automatic control system proposed in the work was evaluated.

Findings. The advantage of the proposed method for controlling the parameters of the mode of electrical distribution networks with symmetric compensating devices over existing ones is proved, because additional criteria, levels of steady stress deviation, are taken into account in the formulation of the control task. The results of computer simulation of the automatic control system, based on the method proposed in the paper, confirmed the results of theoretical studies: the developed automatic control system, in contrast to existing ones, performs such control actions, at which the levels of asymmetry and steady-state stress deviations are observed which do not exceed normally admissible ones.

Originality. For the first time, the solutions of the multicriteria optimization problem were obtained by the method of approaching the Utopian point in the space of criteria for determining the rules for automatic phase-by-phase variation of the reactance of symmetric compensating devices, the application of which allows simultaneous reduction of consumption levels of reactive capacity, asymmetry levels and steady-state voltage deviations in electrical distribution networks with a nominal voltage of up to $1 \mathrm{kV}$.

Practical value. The computer model of the automatic control system of the parameters of the mode of electrical distribution networks with a nominal voltage of up to $1 \mathrm{kV}$ gives possibility to analyze the modes of these networks using it. Also, with the help of this computer model, the process of setting up a microprocessor automatic control system is essentially simplified - based on the method of automatic control of the parameters of the mode of electrical distribution networks proposed in the work.

Keywords: power distribution networks, multi-criteria optimization

Introduction. A characteristic feature of the present is the importance of raising the efficiency of the electrical distribution networks (EDN). As known, the main reason for reducing the efficiency of the EDN is a significant level of power losses in its elements [1, 2]. This concerns, first of all, to EDN with voltage of up to $1 \mathrm{kV}$, the value of electricity losses in which is quite high [3, 4]. One of the basic causes of increasing electrical energy losses in the EDN is overvalues of the unified power quality index (UPQI) on the clips of the electric receivers at the point of their connection $[5,6]$. In the EDN with voltage up to $1 \mathrm{kV}$ the situation is common when levels of the fixed deviation and coefficients of voltage unbalance do not meet the requirements of GOST 13109-97 [7, 8].

One of the most widespread and effective ways of reducing power losses and voltage symmetrization in low voltage EDN is exploitation of the symmetricalcompensating attachments (SCA). But, considering the complex influence of the SCA both on reactive

(C) Plieshkov P. H., Zinzura V.V., Plieshkov S. P., 2019 power consumption and asymmetry consumption, and on the voltage deviation value, also a situation may arise when connecting an SCA to the network, the value of the fixed phase and line voltage deviation will go far beyond the normal limits. Evidently, that in such case the work effectiveness of the EDN is decreasing due to growth of financial loss from the low quality of electric energy. Obviously, in this case, the effectiveness of EDN deteriorates due to the growth of losses from poor-quality electricity. One of the solutions to this problem is to improve the systems of autonomous control (ACS) of SCA with a goal to consider their impact on the levels of voltage deviation in electric networks.

Literature review. In the work [9] the authors proposed to interpret the problem of the reducing of reactive power consumption level and the fixed deviation, and coefficient of asymmetry of voltage reduction as a vector optimization problem. It was also shown that for solution of such class of problems it is appropriate to apply the methods which allow taking into account the norms of GOST 13109-97 for the QPEE to the 
fullest extent possible. The work [10] proposed the ACS for the modes of the EDN with SCA, which considers their complex influence on the levels of the fixed deviation of the voltages. But, the implementation area of the ACS proposed in the work [10] was limited to the networks with nominal voltage between $10-35 \mathrm{kV}$ (high-voltage networks with isolated neutral), so the given ACS cannot be implemented to low voltage EDN, which mostly operate with dead-grounded neutral.

Purpose. The purpose of the work is to increase the efficiency of the operation of electrical distribution networks with nominal voltages up to $1 \mathrm{kV}$ due to the improvement of systems of automatic control of their modes in the presence of symmetry-compensating devices in conditions of asymmetry of voltages.

Results. In order to ensure simultaneous control of the levels of reactive power consumption, deviation levels and voltage unbalance in the EDN, it is necessary to perform per phase change of the reactive resistances of the control sections SCA.

In Fig. 1 the generalized structural scheme of the ACS with the parameters in the EDN mode containing the SCA with the automatic phase change in the reactive resistances of the control sections SCA is given.

In Fig. 1, $\mathrm{CO}$ is the object of control (EDN with SCA); MsrI is the measurer of complex values of the currents; $M s r U$ is the measurer of complex values of the voltages; $R$ is a controller working by predefined algorithm; ACT is the actuator, which ensures the per phase change of reactive resistances of the $\mathrm{SCA}$; $E$ is the matrix of the phase EMF of the power supply system (perturbation, which is immeasurable without additional approach); $\mathbf{Z}_{L}$ is the matrix of phase load complexes (perturbation, which is immeasurable without additional approach); $\boldsymbol{I}$ is the matrix of the current complexes (output of the $\mathrm{CO}$, measurable); $\boldsymbol{U}$ is the matrix of voltage complexes (output of the $\mathrm{CO}$, measurable); $I_{m s r}, U_{m s r}$ are, respectively, the matrices of measured values of complexes for the voltages and currents; $X=\left[X_{1}, X_{2}, X_{3}\right]$ is the control vector (the vector

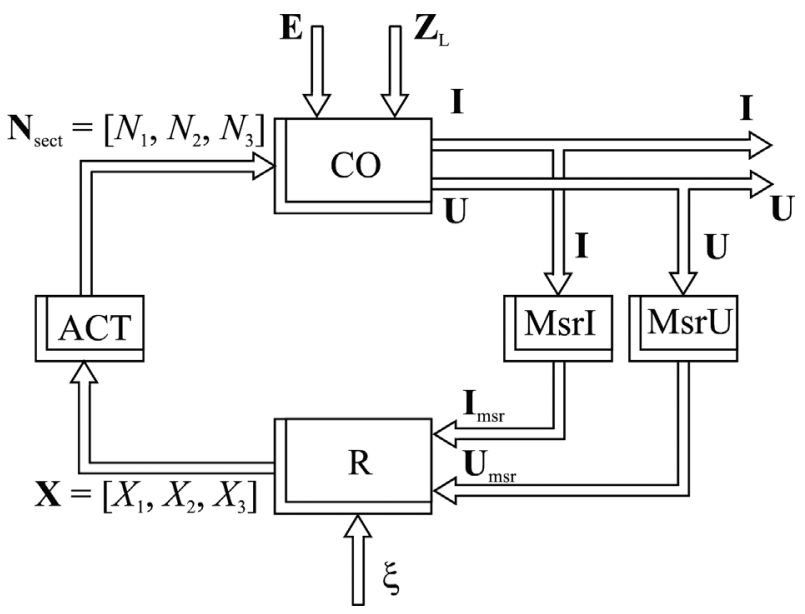

Fig. 1. A generalized structure diagram of the ACS for the mode parameters of the EDN that contains the SCA of reactive resistances of SCA); $N_{\text {sect }}=\left[N_{1}, N_{2}, N_{3}\right]$ is the vector of regulating section numbers per each of static compensation batteries (SCB); $\xi$ is the vector parameters setting.

As we noted early, the problem of the automatic control of the SCA for obtaining the simultaneous regulation of the reactive power consumption levels, the voltage deviation and asymmetry levels in the EDN are the most appropriate to review as a problem of multicriteria optimization. In this case, in contrast to the scalar optimization problem, it is necessary to find a minimum (maximum) of not one, but several criteria at a time. This approach allows us to reach a more acceptable solution for all the optimization criteria.

To accomplish the task of controlling SCA to achieve simultaneous reduction of reactive power consumption levels, voltage deviation and asymmetry levels in form of the problem of multicriteria optimization it is necessary to determine the interrelationships between the input and output parameters of the control object (EDN with SCA).

The replacement scheme of the EDN with nominal voltage $0.4 \mathrm{kV}$, which contains the SCA, combined by the "star with zero" scheme is shown in Fig. 2.

In Fig. 2, $\underline{E}_{A}, \underline{E}_{B}, \underline{E}_{C}$ are the complexes of EMF of the power supply system in phases $A, B, C$ respectively; $R_{s A}, X_{s A}, R_{s B}, X_{s B}, R_{s C}, X_{s C}$ are equivalent active and reactive resistances in phases $A, B, C$ of the power supply system; respectively, complex resistances of the system are $\underline{Z}_{s A}=R_{s A}+j X_{S A}, \underline{Z}_{s B}=R_{s B}+j X_{s B}, \underline{Z}_{S C}=R_{S C}+j X_{S C} ; R_{L A}$, $X_{L A}, R_{L B}, X_{L B}, R_{L C}, X_{L C}$ are active and inductive resistances in phases $A, B, C$ of the equivalent load, connected by the "star" scheme; respectively, the complex resistances of the system are $\underline{Z}_{L A}=R_{L A}+j X_{L A}, \underline{Z}_{L B}=R_{L B}+$ $+j X_{L B}, \underline{Z}_{L C}=R_{L C}+j X_{L C} ; X_{A}, X_{B}, X_{C}$ are capacitive resistances of phases $A, B, C$ of SCA, connected by the star scheme; $\underline{I}_{L A}, \underline{I}_{L B}, \underline{I}_{L C}$ are phase currents in phases $A, B$, $C$ of the load; $\underline{I}_{A}, \underline{I}_{B}, \underline{I}_{C}$ are linear currents in phases $A$, $B, C$ of SCA; $\underline{I}_{S A}, \underline{I}_{S B}, \underline{I}_{S C}$ are phase currents in phases $A$, $B, C$ of the power supply system; $\underline{U}_{A B}, \underline{U}_{B C}, \underline{U}_{C A}$ are linear voltages between phases $A B, B C, C A$ at the point of their connection to SCA and load; $\underline{U}_{A}, \underline{U}_{B}, \underline{U}_{C}$ are phase voltage complexes for phases $A, B, C ; R_{n N}, X_{n N}$ are active and reactive resistances of zero wire (in common

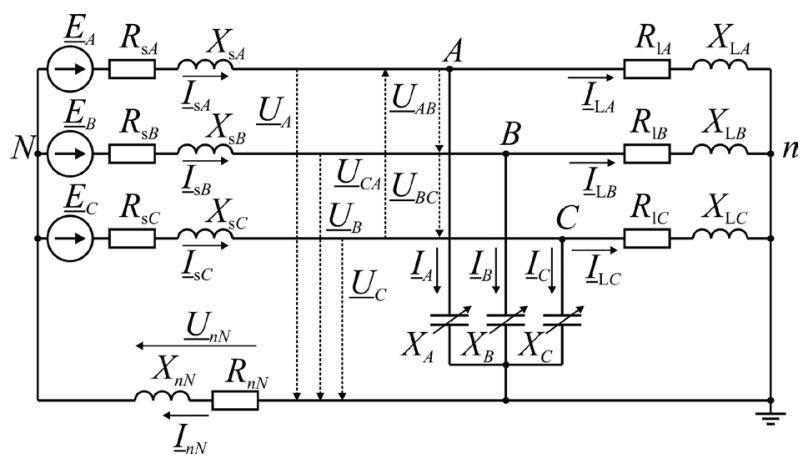

Fig. 2. The scheme of EDN with dead-grounded neutral with $0.4 \mathrm{kV}$ nominal voltage, that contains synchroniccompensating transducers 
case - zero wire and zero sequence resistance of the transformers with the dead-grounded neutral); respectively, the complex of resistance for the zero wire is $\underline{Z}_{n N}=R_{n N}+j X_{n N} ; \underline{U}_{n N}$ is the voltage complex between zero points of load and system; $\underline{I}_{n N}$ is the current in the zero wire.

For the model of the EDN with SCA shown in Fig. 2 in a form of the replacement scheme, the following are characteristic:

- input signals (perturbation, which are immeasurable without special approach): the load resistances of $\underline{Z}_{L A}, \underline{Z}_{L B}, \underline{Z}_{L C}$; EMF of the system $\underline{E}_{A}, \underline{E}_{B}, \underline{E}_{C}$;

- output signals (the signals that are immeasurable without special approach): the load currents $\underline{I}_{L A}, \underline{I}_{L B}$, $\underline{I}_{L C} ;$ the phase voltages $\underline{U}_{A}, \underline{U}_{B}, \underline{U}_{C}$;

- model parameters (values that do not change with a flow of time): resistances of the power supply system $\underline{Z}_{S A}$, $\underline{Z}_{s B}, \underline{Z}_{s C}$; the resistance of zero wire $\underline{Z}_{n N}$;

- regulating influences - capacitive resistances of SCA $X_{A}, X_{B}, X_{C}$.

For the construction of ACS for parameters of the mode of the EDN with SCA is needed to find the relation between the regulating influences $\left(X_{A}, X_{B}, X_{C}\right)$ and output values $\left(\underline{U}_{A}, \underline{U}_{B}, \underline{U}_{C}, \underline{I}_{L A}, \underline{I}_{L B}, \underline{I}_{L C}\right)$, by known model parameters $\left(\underline{Z}_{\mathrm{s} A}, \underline{Z}_{s B}, \underline{Z}_{S C}, \underline{Z}_{n N}\right)$.

The process of seeking the solution of this problem is better to conduct in two stages:

Stage 1. By known measured input signals, model parameters and values of regulating influences at the previous regulation step of the control is needed to determine the values of perturbations that are not directly measurable $\left(\underline{Z}_{L A}, \underline{Z}_{L B}, \underline{Z}_{L C}, \underline{E}_{A}, \underline{E}_{B}, \underline{E}_{C}\right)$.

Stage 2. Having obtained complete information about mathematical model, we need to define the relation between the regulating influences and output parameters.

The equation for the load $\underline{Z}_{L A}, \underline{Z}_{L B}, \underline{Z}_{L C}$ resistances calculation has the following form

$$
\left\{\begin{array}{l}
\underline{Z}_{L A}=R_{\grave{A} A}+j X_{L}=\frac{\underline{U}_{A}}{\underline{I}_{L A}} \\
\underline{Z}_{L B}=R_{L B}+j X_{L B}=\frac{\underline{U}_{B}}{\underline{I}_{L B}} \\
\underline{Z}_{L C}=R_{L C}+j X_{L C}=\frac{\underline{U}_{? C}}{\underline{I}_{L C}}
\end{array}\right.
$$

For the definition of the EMF for $\underline{E}_{A}, \underline{E}_{B}, \underline{E}_{C}$ it is needed to do some transformations of replacement scheme of the EDN, which is depicted in Fig. 3, where $\underline{Z}_{e A}, \underline{Z}_{e B}, \underline{Z}_{e C}$ are the equivalent complex resistances by phases of the EDN, which are defined from the next equation

$$
\left\{\begin{array}{l}
\underline{Z}_{e A}=\underline{Z}_{s A}+\underline{Z}_{A}^{\prime} \\
\underline{Z}_{e B}=\underline{Z}_{s B}+\underline{Z}_{B}^{\prime} \\
\underline{Z}_{e C}=\underline{Z}_{s C}+\underline{Z}_{C}^{\prime}
\end{array}\right.
$$

where $\underline{Z}_{A}^{\prime}, \underline{Z}_{B}^{\prime}, \underline{Z}_{C}^{\prime}$ are the equivalent complex load resistances by phases of the SCA, the equations for which has the following form
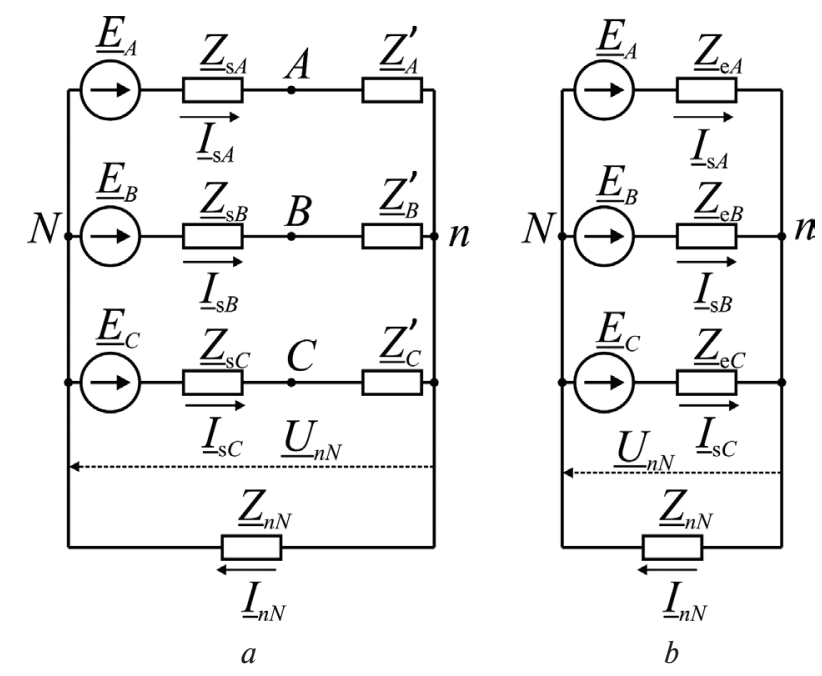

Fig. 3. Replacement scheme of the EDN:

$a$ - before equivalent transformations; $b$ - after equivalent transformations

$$
\left\{\begin{array}{l}
\underline{Z}_{A}^{\prime}=\frac{j X_{A} \underline{Z}_{L A}}{j X_{A}-\underline{Z}_{L A}} \\
\underline{Z}_{B}^{\prime}=\frac{j X_{B} \underline{Z}_{L B}}{j X_{B}-\underline{Z}_{L B}} \\
\underline{Z}_{C}^{\prime}=\frac{j X_{C} \underline{Z}_{L C}}{j X_{C}-\underline{Z}_{L C}}
\end{array}\right.
$$

For the definition of the EMF of the system it is needed to define the voltage $\underline{U}_{n N}$. To do this, for the scheme in the Fig. 3,b) it is most appropriate to use the method of the nodal potentials, according to which the voltage of $U_{n N}$ is defined by the following equation

$$
\underline{U}_{n N}=-\frac{\frac{\underline{E}_{A}}{\underline{Z}_{\dot{A}}}+\frac{\underline{E}_{B}}{\underline{Z}_{e B}}+\frac{\underline{E}_{C}}{\underline{Z}_{e}}}{\frac{1}{\underline{Z}_{e A}}+\frac{1}{\underline{Z}_{e B}}+\frac{1}{\underline{Z}_{e C}}+\frac{1}{\underline{Z}_{n N}}} .
$$

Considering the equation (4), the EMF of the system $\underline{E}_{A}, \underline{E}_{B}, \underline{E}_{C}$ is defined by the equation

$$
\left\{\begin{array}{l}
\underline{E}_{A}=-\underline{U}_{A}-\underline{U}_{n N} \\
\underline{E}_{B}=-\underline{U}_{B}-\underline{U}_{n N} . \\
\underline{E}_{C}=-\underline{U}_{C}-\underline{U}_{n N}
\end{array}\right.
$$

The second stage of solving the problem of determining the relationship between the input and output parameters of the control object is in finding the dependence values of the currents $\underline{I}_{\mathrm{s} A}, \underline{I}_{\mathrm{s} B}, \underline{I}_{\mathrm{s} C}, \underline{I}_{n N}$, and the voltages $\underline{U}_{A}, \underline{U}_{B}, \underline{U}_{C}$ from the regulating influences of $X_{A}$, $X_{B}, X_{C}$. The solution of the given problem is best to get by finding appropriate solutions of the system of linear algebraic equations, compiled according to Kirchhoff's first and second laws for the substitution scheme, depicted in Fig. 3, b). 
Final equations to find dependence of currents $\underline{I}_{s A}$, $\underline{I}_{s B}, \underline{I}_{S C}, \underline{I}_{n N}$ on the values of regulating influences $X_{A}$,
$X_{B}, X_{C}$, considering equations $(2,3)$ has the following form

$$
\left\{\begin{array}{l}
\underline{I}_{s A}=\frac{\underline{E}_{A}\left[\underline{Z}_{e B} \underline{Z}_{e C}+\underline{Z}_{n N}\left(\underline{Z}_{e B}+\underline{Z}_{e C}\right)\right]-\underline{Z}_{n N}\left(\underline{E}_{B} \underline{Z}_{e C}+\underline{E}_{C} \underline{Z}_{e B}\right)}{\underline{Z}_{e A} \underline{Z}_{e B} \underline{Z}_{e C}+\underline{Z}_{n N}\left(\underline{Z}_{e A} \underline{Z}_{e B}+\underline{Z}_{e A} \underline{Z}_{e C}+\underline{Z}_{e B} \underline{Z}_{e C}\right)} \\
\underline{I}_{S B}=\frac{\underline{E}_{B}\left[\underline{Z}_{e A} \underline{Z}_{e C}+\underline{Z}_{n N}\left(\underline{Z}_{e A}+\underline{Z}_{e C}\right)\right]-\underline{Z}_{n N}\left(\underline{E}_{C} \underline{Z}_{e A}+\underline{E}_{A} \underline{Z}_{e C}\right)}{\underline{Z}_{e A} \underline{Z}_{e B} \underline{Z}_{e C}+\underline{Z}_{n N}\left(\underline{Z}_{e A} \underline{Z}_{e B}+\underline{Z}_{e A} \underline{Z}_{e C}+\underline{Z}_{e B} \underline{Z}_{e C}\right)} \\
\underline{I}_{S C}=\frac{\underline{E}_{C}\left[\underline{Z}_{e A} \underline{Z}_{e B}+\underline{Z}_{n N}\left(\underline{Z}_{e A}+\underline{Z}_{e B}\right)\right]-\underline{Z}_{n N}\left(\underline{E}_{A} \underline{Z}_{e B}+\underline{E}_{B} \underline{Z}_{e A}\right)}{\underline{Z}_{e A} \underline{Z}_{e B} \underline{Z}_{e C}+\underline{Z}_{n N}\left(\underline{Z}_{e A} \underline{Z}_{e B}+\underline{Z}_{e A} \underline{Z}_{e C}+\underline{Z}_{e B} \underline{Z}_{e C}\right)} \\
\underline{I}_{n N}=\underline{I}_{s A}+\underline{I}_{s B}+\underline{I}_{S C}
\end{array} .\right.
$$

The dependence of phase voltages $\underline{U}_{A}, \underline{U}_{B}, \underline{U}_{C}$ on values of the regulating influences $X_{A}, X_{B}, X_{C}$, considering the equations $(2,3,6)$ is found by solving the system of equations according to second law of Kirchhoff for the scheme depicted in Fig. 3, a), and appear as follows

$$
\left\{\begin{array}{l}
\underline{E}_{A}=-\underline{U}_{A}-\underline{U}_{n N} \\
\underline{E}_{B}=-\underline{U}_{B}-\underline{U}_{n N} . \\
\underline{E}_{C}=-\underline{U}_{C}-\underline{U}_{n N}
\end{array} .\right.
$$

Therefore, the equations found (2-7) depict the relations between input and output parameters of the object of control (EDN with SCA).

As we noted above, the problem of decreasing the reactive load usage, values of voltage deviation and coefficients of the voltage asymmetry with use of SCA which is most appropriate to interpret as a vector optimization problem. For the EDN on the nominal voltage up to $1 \mathrm{kV}$, that contains the SCA, the control sections of which are connected by the star scheme, setting the task of automatic control of their mode looks as follows

$$
\left\{\begin{array}{l}
\operatorname{tg} \varphi(X)=\frac{Q_{s}(X)}{P_{s}(X)} \rightarrow \min \\
\Delta U_{1}(X)=\left|\frac{U_{1}(X)-U_{\text {nom }}}{U_{n o m}}\right| \cdot 100 \rightarrow \min \\
k_{2 U}(X)=\frac{U_{2}(X)}{U_{n o m}} \cdot 100 \rightarrow \min \\
k_{0 U}(X)=\frac{U_{0}(X)}{U_{n o m}} \cdot 100 \rightarrow \min \\
\Delta U_{p h i}(X)=\left|\frac{U_{p h i}(X)-U_{\text {nom.ph }} \mid}{U_{\text {nom.ph }}}\right| \cdot 100 \rightarrow \min \\
X \in \Omega
\end{array},\right.
$$

where $X=\left[X_{A}, X_{B}, X_{C}\right]$ is the vector of the reactive phase resistances of SCA (vector of control); $\operatorname{tg} \varphi(X)$ is the reactive power factor; $P_{s}(X), Q_{s}(X)$ are, respectively, active and reactive powers, which are consumed from the system; $U_{1}(X)$ is the module of the active value of the direct-sequence voltage; $\Delta U_{1}(X)$ is stable deviation of three phase voltage of the network; $U_{\text {nom }}$ is the nominal linear voltage in the network; $k_{2 U}(X)$ is the asymmetry coefficient for the voltages of inverse sequence; $U_{2}(X)$ is the mode of the active value of the inverse sequence voltage; $k_{0 U}(X)$ is the voltage asymmetry coefficient by zero sequence; $U_{0}(X)$ is the mode of the active value of the zero sequence voltage; $\Delta U_{p h i}(X), i=A, B, C$ is stable phase voltage deviation of the network per phases $A, B$, $C$; $U_{\text {nom.ph }}$ is the nominal phase voltage of the network; $\Omega=R^{3}\left|X_{i \min } \leq X_{i} \leq X_{i \max }\right|$ is the scope of admissible controls $X$, defined by the range of regulation SCA; $X_{i \text { min }}$, $X_{i \max }$ are minimal and maximal values of reactive phase resistances of the SCA.

In the work [10] it was shown, that the most effective way for solving the problems that are similar to (8), is the method of approach to the ideal-point. A problem solving procedure by the noted method is performed in two stages:

Stage 1. Finding the ideal-point coordinates $Q_{u t}=$ $=\left(\operatorname{tg} \varphi_{u t}, \Delta U_{1 u t}, k_{2 U u t}, k_{0 U u t}, \Delta U_{\text {phiut }}\right)$ in a criteria space $Q \subset R^{7}$ as a result of finding the minimum of each of the criterion functions that are part of the task statement (8).

Stage 2. Finding the final solution of the problem of optimization in regulation space $\Omega \subset R^{3}$ (vector of optimal control $\boldsymbol{X}^{*}$ ) as a result of the distance minimizing $\rho$ between the ideal point and the pareto-optimal set of solutions.

As a result of the conducted research of the criterion functions, it was established that the obtained analytical dependences for determining the coordinates of the ideal point are rather cumbersome and unsuitable for practical application. So, in our opinion, to solve this problem, it is most appropriate to apply one of the numerical methods of conditional optimization of the function of many variables.

As we noted above, finding the final solution to the problem (8) is reduced to minimizing the Euclidean distance between the ideal point and the pareto-optimal set

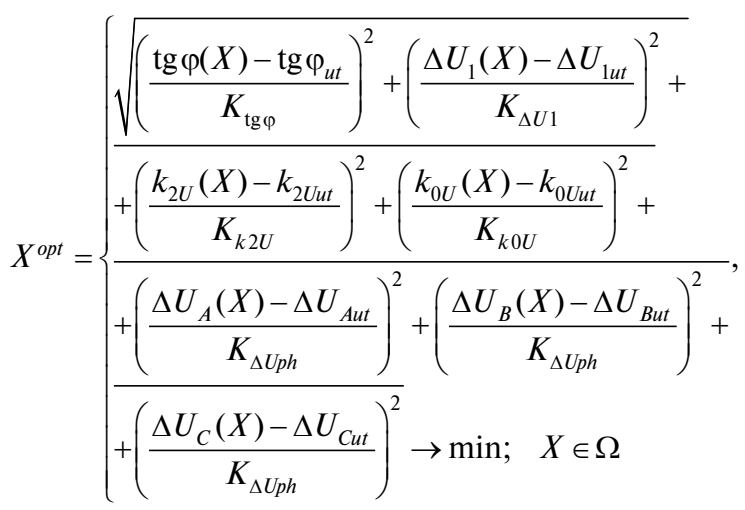


where $X^{\text {opt }}$ is the vector of optimal control; $K_{\operatorname{tg} \varphi}, K_{\Delta U 1}$, $K_{k 2 U}, K_{k 0 U}, K_{\Delta U p h}$ are the coefficients for calculation of the relative weight of the optimization criteria. Numeral values of these coefficients are found heuristically based on priory information and specified as a result of the imitational modeling and in an exploitation process. In the work [9] for definition of the coefficients $K_{\Delta U 1}, K_{k 2 U}$, $K_{k 0 U}, K_{\Delta U p h}$ it is proposed to apply a normally allowable value of respective UPQI and for the $K_{\operatorname{tg} \varphi}-$ a value of the reactive load coefficient set by the power supply organization.

Consequently, the solution of the problem (8) reduces to the solution of a series of 8 scalar conditional optimization problems of the function of many variables. As the results of the calculations have shown, to solve the noted optimization problems, it is most appropriate to use the Nelder-Mead's method, which belongs to the class of non-gradient numerical optimization methods. The choice of this method is grounded, first of all, by its high reliability and performance, as well as the ease of implementation, which is its main advantage over other methods, due to the microcontroller implementation of ACS.

Basing on the founded solution for the problem of multicriteria optimization, a structural scheme of distribution networks of automatic control system mode was developed with synchro-compensation transducers, which is shown in Fig. 4.

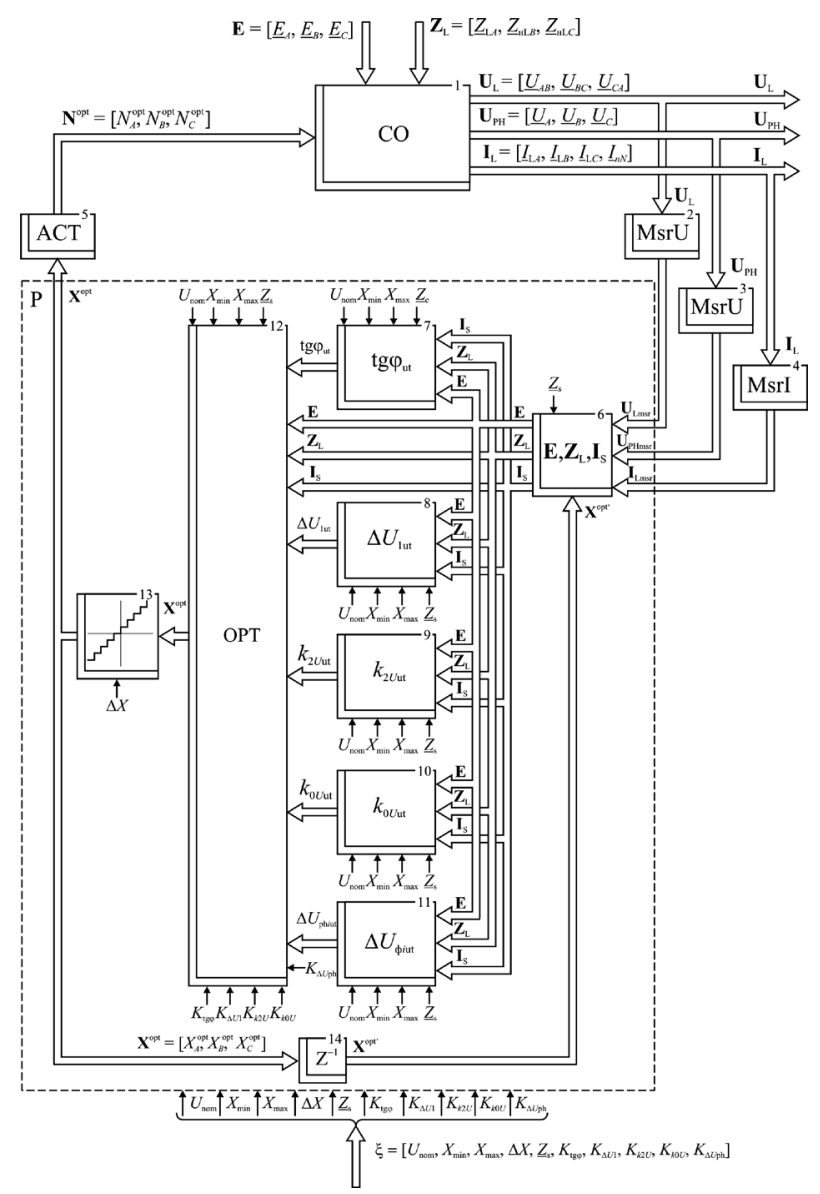

Fig. 4. Structural diagram of the ACS for modes of the EDN with SCA for the case of network with 3 deadgrounded neutral
In Fig. $4, \boldsymbol{E}=\left[\underline{E}_{A}, \underline{E}_{B}, \underline{E}_{C}\right]$ is the vector of the complexes of the EMF of the power supply system; $\boldsymbol{U}_{L}=$ $=\left[\underline{U}_{A B}, \underline{U}_{B C}, \underline{U}_{C A}\right]$ is the vector of the complexes of the linear voltages at the point of connection of the SCA and the equivalent load; $\boldsymbol{U}_{L m s r}=\left[\underline{U}_{A B m s r}, \underline{U}_{B C m s r}, \underline{U}_{C A m s r}\right]$ is the vector of the measured values of complexes of linear voltages at the point of connection of the SCA and the equivalent load; $\boldsymbol{U}_{P H}=\left[\underline{U}_{A}, \underline{U}_{B}, \underline{U}_{C}\right]$ is the vector of the of the complexes of the phase voltages at the point of connection of the SCA and the equivalent load; $\boldsymbol{U}_{P H m s r}=\left[\underline{U}_{A m s r}, \underline{U}_{B m s r}, \underline{U}_{C m s r}\right]$ is the vector of the measured values of complexes of phase voltages at the point of connection of the SCA and the equivalent load; $Z_{L}=\left[\underline{Z}_{L A}, \underline{Z}_{L B}, \underline{Z}_{L C}\right]$ is the vector of the equivalent load complex resistances, connected by the star scheme; $\boldsymbol{I}_{S}=$ $=\left[\underline{I}_{s A}, \underline{I}_{s B}, \underline{I}_{S C}\right]$ is the vector of the complexes of the linear currents in phases $A, B, C$ in the network of the power supply system; $\boldsymbol{I}_{L}=\left[\underline{I}_{L A}, \underline{I}_{L B}, \underline{I}_{L C}\right]$ is the vector of the linear currents complexes in phases $A, B, C$ and the zero wire in the load circuit; $\boldsymbol{I}_{L m s r}=\left[\underline{I}_{L A m s r}, \underline{I}_{L B m s r}, \underline{I}_{L C m s r}\right]$ is the vector of the measured values of linear currents complexes in phases $A, B, C$ and the zero wire in the load circuit; $\xi=\left[U_{\text {nom }}, X_{\min }, X_{\max }, \Delta X, \underline{Z}_{s}, K_{\operatorname{tg} \varphi}, K_{\Delta U 1}\right.$, $\left.K_{k 2 U}, K_{k 0 U}, K_{\Delta U p h}\right]$ is the vector of the parameters setting; $X_{\min }, X_{\max }$ is the respective minimal and maximal values of capacitive resistance SCA (for minimal and maximal values of control vector); $\Delta X$ is the step of the capacitive resistance change for SCA (regulation step); the article regarded a constructive version of execution of the $\mathrm{SCA}$, for which $\Delta X$ is the same per each of phases of the SCA in the whole range of regulation; $\underline{Z}_{s}$ is the complex value of phase resistances of the power supply system; although the developed mathematical models allow considering the phase resistance asymmetry power supply system, the article studied the case when the resistances of the power supply system are symmetrical; $X^{\mathrm{opt}}=\left(X_{A}^{\mathrm{opt}}, X_{B}^{\mathrm{opt}}, X_{C}^{\mathrm{opt}}\right)$ is the vector of optimal control; $N^{\mathrm{opt}}=\left(N_{A}^{\mathrm{opt}}, N_{B}^{\mathrm{opt}}, N_{B}^{\mathrm{opt}}\right)$ is the vector of numeric values of the sections of SCA, that correspond to the vector of optimal control $X^{\text {opt }} ; X^{\mathrm{opt}^{\prime}}=\left(X_{A}^{\mathrm{opt}^{\prime}}, X_{B}^{\mathrm{opt}^{\prime}}, X_{C}^{\mathrm{opt}^{\prime}}\right)$ is the vector of optimal control, which is found at previous calculation step; 1 is the object of control (EDN with SCA); 2, 3 are primary measuring transducers of three phase voltages(measurers for complexes of linear and phase voltages); constructively, blocks 1, 2 are combined in the form of singular device - measuring voltage of the transformer; 4 is a primary load current measuring transducer (a measurer of linear current complexes in the load network); 5 is an actuator - the contactor, which performs per phase switching of the sections of the SCA; 6 is a calculation block for vectors $E, Z_{L}, I_{S} ; 7,8,9,10,11$ are calculation blocks for ideal point coordinates $\operatorname{tg} \varphi_{u t}, \Delta U_{1 u t}, k_{2 \text { Uut }}, k_{0 \text { Uut }}, \Delta U_{\text {phiut }} ; 12$ is a block of the vector of optimal control of $X^{o p t}$ calculation; in the given block the optimization problem is solved (9) by the realization of optimization algorithm according to the Nelder-Mead's method chosen in the article; 13 is the sampling block for the values of capacitive resistances of phases for SCA; 14 is the transport block (temporal) for signal delay at the first stage of the sampling. 
The ACS, whose structural scheme is shown in Fig. 4, works in the following way: measured values of vectors $\boldsymbol{U}_{L}, \boldsymbol{U}_{P H}$ and $\boldsymbol{I}_{L}$ along with values of $X^{\text {opt }}$ and $\underline{Z}_{s}$ move to block 6, in which the calculation of vectors $\boldsymbol{E}$, $Z_{L}, I_{S}$ is conducted. Then, the values of $E, Z_{L}, I_{S}$ together with values $U_{\text {nom }}, X_{\min }, X_{\max }, \underline{Z}_{s}$ are sent to blocks 7,8 , $9,10,11$, in which the coordinate of the ideal-points are calculated for $\operatorname{tg} \varphi_{\text {?? }}, \Delta U_{1 u t}, k_{2 \text { Uut }}, k_{0 \text { Uut }}, \Delta U_{\text {phiut }}$ respectively. Then, the data from blocks $7,8,9,10,11$ together with values of the vector $\xi$ is sent to block 12, in which the final solution of the problem (8) is defined - the vector of optimal control $X^{\text {opt }}$. The value of vector $X^{\text {opt }}$ from block 12 together with the value of $\Delta X$ then move to block 13 , in which the sampling is conducted for the found control vector according to the level. The obtained resulting value of the control vector from block 13 sent to the block of the transport delay of the signal 14 . From the delay block of the signal 14 the value of $X^{\text {opt }}$ then is sent to block 6, thereby, as in the previous case, forming an internal loop of feedback. In addition to this value the vector of optimal control $X^{\text {opt }}$ from block 13 is then sent to the actuator - block 5, which conducts the switching of the control sections of SCA, that set them in accordance to the vector $N^{\text {opt }}$.

The study of the proposed method for automatic control of the parameters of the mode of electric networks, based on the solution of the problem (8), was carried out by computer simulation. To do this, based on the above described ACS structural scheme, a computer simulation model was developed in the Matlab/ Simulink environment (Fig. 5).

Fig. 5 shows "EFC" - an electromotive force change over the time setup block; "Load" - an electric load change over the time setup block; as the basic data for the modeling there were used real experimental data of the dial reactive and active electric load surveys, which were founded through exploitation of certificated network analyzer FLUKE 1744 Memobox on a substation of PJC company "Kirovohradoblenerho"; "EDN with SCA" - a distributive electric network model block;

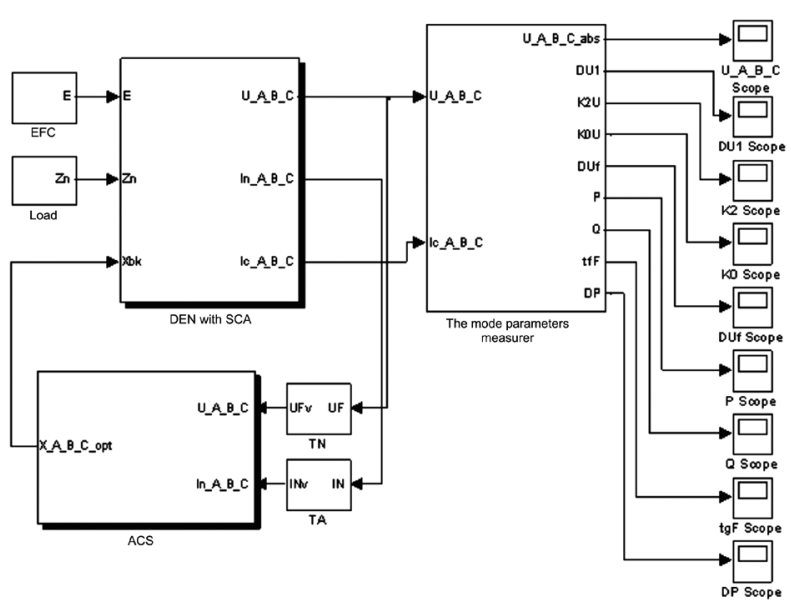

Fig. 5. General model of the ACS for modes of the EDN with SCA in a case of network with the dead-grounded neutral for the Matlab Simulink
"ACS" - a model of ACS for the electrical modes, which is based on the developed structural scheme (Fig. 1). "TN" - a model of the voltage transformer; "TA" - a model of the current transformer; "The mode parameters measurer" - a model of the measurer of the mode parameters, that gets the initial data which is sent to virtual oscilloscopes (blocks of the "Scope"), which allow visualizing the modeling results.

To study the effect of the application of the developed ACS, a comparative computer simulation of the work of the developed and basic ACS for EDN was carried out, the principal scheme of which is depicted in Fig. 6.

The control system that was chosen as the base provides reduction of reactive power consumption and voltage asymmetry coefficients $k_{2 U}(X)$ and $k_{0 U}(X)-$ without taking into consideration the SCA influence onto the linear and phase voltages of the network deviations.

The results of comparative computer simulation for the case of developed and basic ACS by the mode parameters are shown in Figs. 7-11.

In Figs. 7-11, $a$ is the basic model; $b$ is the developed model.

Statistical analysis indexes of the computer simulation results are shown in Table.

As it is evident from the results of the studies presented in Table, with the application of the base model of ACS the value of the steady-state deviation of the three-phase voltage $\Delta U_{1}$ are observed, which do not meet the requirements of GOST 13109-97 relative to this UPQI $(P(\Delta U \leq 5 \%)=0)$. Similar results are also gained for the phase voltages, namely in the phases $\mathrm{A}$ $\left(P\left(\Delta U_{A}<5 \%\right)=0\right)$ and $\mathrm{B}\left(P\left(\Delta U_{B}<5 \%\right)=0\right)$. In case of application of the ACS developed in article, the levels of the tree-phase voltage deviation $\Delta U_{1}$ and voltages in the phases A, B correspond to the norms of GOST 13109-97 accordingly to this UPQI $\left(P\left(\Delta U_{1}<5 \%\right)=1, P\left(\Delta U_{A}<\right.\right.$ $\left.<5 \%)=1, P\left(\Delta U_{B}<5 \%\right)=1\right)$. Also from the table it is clear that the values of the coefficients of asymmetry $k_{2 U}$ and $k_{0 U}$ for both cases of the modeling meet the requirements of GOST 13109-97.

Despite the fact that application of the developed ACS model gives a bit higher value of the reactive power coefficient than in case of use of the basic ACS model $\left(M\left(\operatorname{tg} \varphi_{\text {devel }}\right)=0.46>M\left(\operatorname{tg} \varphi_{\text {basic }}\right)=0.121\right)($ and, as a result, insignificantly higher values of the active power loses $\Delta W_{\text {day.devel }}=345.1 \mathrm{~kW} \times \mathrm{h}>\Delta W_{\text {day.basic }}=295.5 \mathrm{~kW} \times$ $\times \mathrm{h}$ ), which allows concluding that the proposed ACS model has greater effectiveness than the basic one due to the establishment of such management influences, for which the noted UPQI totally corresponds to the requirements of the GOST 13109-97. That was caused by norms of the GOST 13109-97, according to which if the QPEE limits are exceeded, it is imperative to make mea-

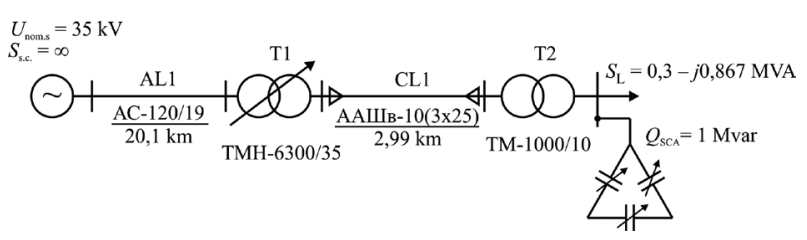

Fig. 6. A principal scheme of EDN 


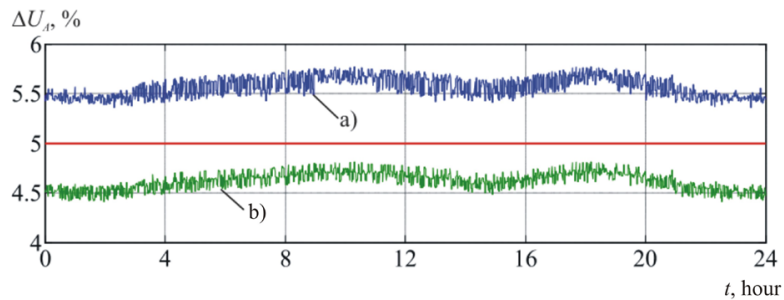

Fig. 7. Charts of the deviation of $\Delta U_{A}$

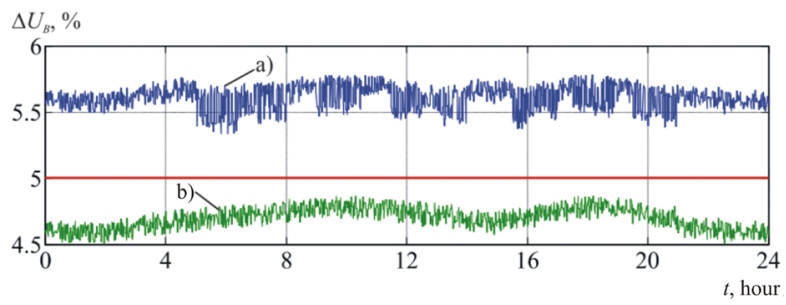

Fig. 8. Charts of the deviation of $\Delta U_{B}$

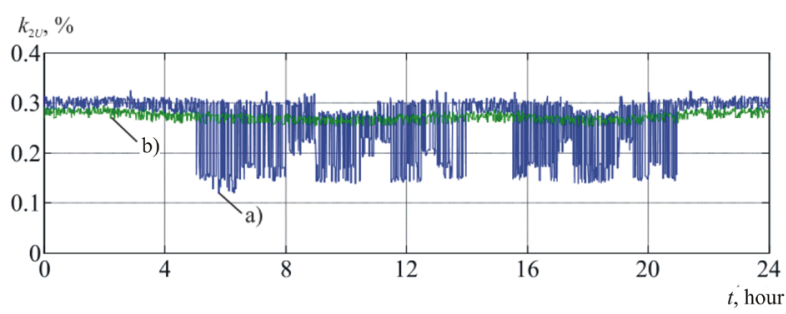

Fig. 9. Charts of the changes for $k_{2 U}$

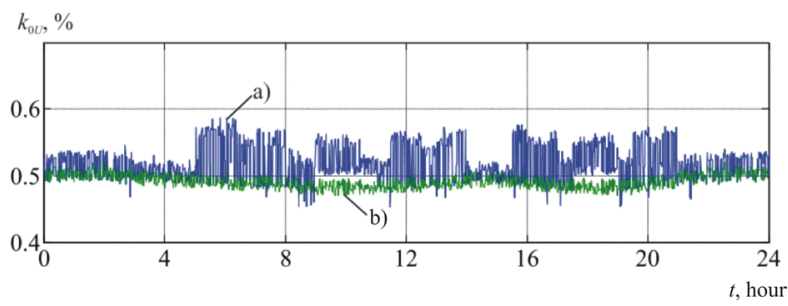

Fig. 10. Charts of the changes for $k_{0 U}$

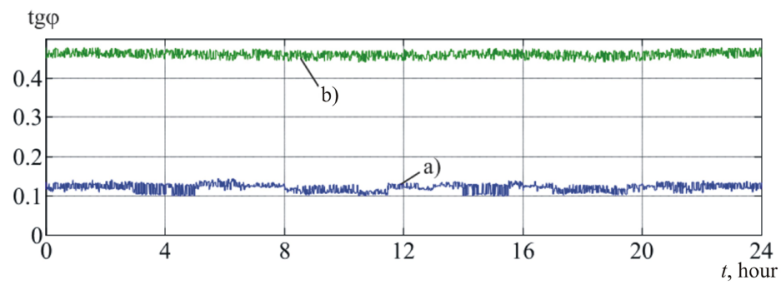

Fig. 11. Charts of the changes for $\operatorname{tg} \varphi$

sures to improve the quality of electric energy without substantiating their expediency by technical and economic calculations.

Conclusions. As a result of the research, the following conclusions can be drawn:

1. Formalization of the task of controlling the parameters of the EDN modes with SCA in the presence of voltage asymmetry for the case of low-voltage networks showed that it reduces to the vector optimization problem.
Table

Statistical processing of the computer simulation results

\begin{tabular}{|c|c|c|c|c|}
\hline № & $\begin{array}{c}\text { The parameter } \\
\text { of model state }\end{array}$ & $\begin{array}{c}\text { Mathematical } \\
\text { expectation, } M\end{array}$ & $\sigma^{2}$ & $\begin{array}{c}P\left(x<x_{n . v}\right), \\
\text { p.u. }\end{array}$ \\
\hline \multicolumn{5}{|c|}{ Basic model of the ACS } \\
\hline 1. & $\Delta U_{1}, \%$ & 5.221 & 0.073 & 0 \\
\hline 2. & $k_{2 U}, \%$ & 0.258 & 0.060 & 1 \\
\hline 3. & $k_{0 U}, \%$ & 0.517 & 0.027 & 1 \\
\hline 4. & $\Delta U_{A}, \%$ & 5.568 & 0.099 & 0 \\
\hline 5. & $\Delta U_{B}, \%$ & 5.610 & 0.091 & 0 \\
\hline 6. & $\Delta U_{C}, \%$ & 4.487 & 0.104 & 1 \\
\hline 7. & $\operatorname{tg} \varphi$, в.о. & 0.121 & 0.010 & - \\
\hline 8. & $\Delta W_{\text {day }}, \mathrm{kW} \times \mathrm{h}$ & & 295.5 \\
\hline \multicolumn{5}{|c|}{ The developed model of the ACS } \\
\hline 9. & $\Delta U_{1}, \%$ & 4.294 & 0.090 & 1 \\
\hline 10. & $k_{2 U}, \%$ & 0.272 & 0.009 & 1 \\
\hline 11. & $k_{0 U}, \%$ & 0.492 & 0.010 & 1 \\
\hline 12. & $\Delta U_{A}, \%$ & 4.619 & 0.087 & 1 \\
\hline 13. & $\Delta U_{B}, \%$ & 4.697 & 0.079 & 1 \\
\hline 14. & $\Delta U_{C}, \%$ & 3.566 & 0.105 & 1 \\
\hline 15. & $\operatorname{tg} \varphi$, в.о. & 0.46 & 0.008 & - \\
\hline 16. & $\Delta W_{\text {day }}, \mathrm{kW} \times \mathrm{h}$ & & 345.1 \\
\hline
\end{tabular}

2. The most expedient method of finding the solution of this problem is a method based on minimizing the distance from the ideal point to the pareto-optimal set of solutions. By using this method, the requirements for levels of compensation of reactive loads, as well as requirements that normalize the fixed deviation and asymmetry of stresses in the EDN, which are regulated by the GOST 13109-97, can most fully be taken into account for the quality parameters of electric energy.

3. The analysis of computer modeling results of developed ACS of electric modes has shown that in case of application of the proposed ACS the values of the stable three-phased voltage deviation $\Delta U_{1}$ and phase voltages in the phases $\mathrm{A}, \mathrm{B}$, in difference from basic ACS, meet the requirements of the GOST 13109-97 $\left(P\left(\Delta U_{1}<\right.\right.$ $\left.<5 \%)=1, P\left(\Delta U_{A}<5 \%\right)=1, P\left(\Delta U_{B}<5 \%\right)=0\right)$. At the same times the levels of $k_{2 U}$ and $k_{0 U}$ both in case of basic model of the ACS, and in the case of the developed model of the ACS meet the current regulatory requirements.

When applying the developed model there is a slightly higher value of the reactive power factor than in case of the basic model $\left(M\left(\operatorname{tg} \varphi_{\text {devel }}\right)=0.46>M\left(\operatorname{tg} \varphi_{\text {basic }}\right)=\right.$ $=0.121)$, and, as a result, by $14.4 \%$ greater value of active electric power loses. However, even without conducting technical and economic calculations, it can be concluded that the proposed ACS is more effective than the basic one due to the establishment of such management influences in which the quality parameters of electric energy totally correspond to norms of the GOST 13109-97. 


\section{References.}

1. Buslavets, O.A., Burykin, O. B., \& Lezhnyuk, P.D. (2016). The impact of transit overflows of power on losses in the power grids. Tekhnichna Elektrodynamika, 4, 71-73.

2. Lezhnyuk, P.D., Rubanenko, A.E., \& Kylymchuk, A. V. (2014). Minimization of additional losses of electricity in electric networks by means of cross transformers. Enerhetyka: ekonomika, tekhnolohii, ekolohiia, 3, 7-14.

3. Sotnik, O. V. (2016). Analysis of technical metods for reduction loses of electricity in rual electric networks 0.4 kV. Visnyk KhNTUSGh im. P. Vasylenka. Tekhnichni nauky, 175, 151-152.

4. Furman, I. O., \& Miroshnyk, O. O. (2015). Assessment of inhomogeneous modes and loss of electric energy in power supply systems. Visnyk KhNTUSGh im. P. Vasylenka. Tekhnichni nauky, 164, 14-15.

5. Popova, I.O., Nesterchuk, D. M., \& Popriadukhin, V. S. (2017). Analysis of the influence of asymmetric loads on the modes of operation of a three-phase asynchronous electric motor. Visnyk KhNTUSGh im. P. Vasylenka. Tekhnichni nauky, 13, 85-87.

6. Stiopin, Yu.O., Borokhov, I.V., \& Perova, N.P. (2015). Estimation of loss of power of asynchronous electric motors at voltage unbalance. Pratsi Tavriiskoho derzhavnoho ahrotehnolohichnoho universytetu: naukove fakhove vydannia, 15, 323-327.

7. Saienko, Yu. L., \& Kaliuzhnyi, D. M. (2017). A general mathematical model for the distribution of actual contributions to distortion of symmetry and deviation of voltage at the point of general accession. Visnyk Vinnytskoho politekhnichnoho instytutu, 6, 80-85.

8. Saienko, Yu., \& Kaliuzhnyi, D. M. (2015). Analytical methods for determination of the factual contributions impact of the objects connected to power system on the distortion of symmetry and sinusoidal waveform of voltages. Przeglad elektrotechniczny, 15, 81-85.

9. Zinzura, V. V. (2012). Methods of multi-objective optimization solution for the problem of voltage regulation in electrical networks. Zbirnyk naukovykh prats Kirovohradskoho natsionalnoho tekhnichnoho Universytetu. Tekhnika v silskohospodarskomu vyrobnytstvi, haluzeve mashynobuduvannia, avtomatyzatsiia, 25(1), 350-360.

10. Taranukha, M.S., Teliuta, R. V., \& Zinzura, V.V. (2015). Optimal control regimes reactive load conditions asymmetry voltage electrical distribution networks. Visnyk Natsionalnoho tekhnichnoho universytetu "Kharkivskyi politekhnichnyi instytut". Zbirnyk naukovykh prats. Tematychnyi vypusk: Problemy udoskonalennia elektrychnykh mashyn i aparativ. Teoriia i praktyka, 42, 62-66.

\section{Автоматичне керування режимом електричних мереж при несиметрії напруг}

\section{П. Г. Плєшков, В. В. Зінзура, С. П. Плєшков}

Центральноукраїнський національний технічний університет, м. Кропивницький, Україна, e-mail: vasiliyzinzura@ gmail.com
Мета. Підвищення ефективності роботи розподільних електричних мереж номінальною напругою до 1 кВ за рахунок удосконалення систем автоматичного керування їх режимами за наявності симетрокомпенсуючих пристроїв в умовах несиметрії напруг.

Методика. Методи векторної оптимізації були застосовані при вирішенні задачі керування параметрами режиму розподільних електричних мереж. Методи чисельної оптимізації функції багатьох змінних були використані для знаходження розв'язку задачі векторної оптимізації. За допомогою методу комп'ютерного моделювання була проведена оцінка ефективності розробленої системи автоматичного керування.

Результати. Доведені переваги розробленого методу керування режимами розподільних мереж із симетро-компенсуючими пристроями над існуючими за рахунок урахування в постановці задачі керування додаткових критеріїв, а саме рівнів усталеного відхилення фазних і лінійних напруг. Результати комп'ютерного моделювання розробленої системи автоматичного керування, в основу якої покладено запропонований у роботі метод, підтвердили результати теоретичних досліджень: розроблена система автоматичного керування, на відміну від існуючих, здійснює такі керуючі впливи, за яких спостерігаються нормально допустимі значення коефіцієнтів несиметрії та усталеного відхилення напруг, що задовольняють нормативним вимогам відносно вказаних показників якості електроенергії.

Наукова новизна. Уперше отримані розв'язки задачі векторної оптимізації на основі використання методу наближення до ідеальної точки у просторі критеріїв для визначення алгоритму автоматичної пофазної зміни реактивних опорів симетрокомпенсуючих пристроїв, застосування яких дозволяє досягти одночасного зниження рівнів споживання реактивної потужності, значень коефіцієнтів несиметрії за зворотної та нульової послідовності, та значень усталеного відхилення напруг у розподільних електричних мережах номінальною напругою до 1 кВ.

Практична значимість. Розроблена комп'ютерна модель системи автоматичного керування дозволяє проводити дослідження режимів розподільних електричних мереж номінальною напругою до 1 кВ. Також за допомогою цієї комп'ютерної моделі суттєво спрошується процес налаштування мікропроцесорної системи автоматичного керування, в основу якої покладено запропонований у роботі метод автоматичного керування параметрами режиму розподільних електричних мереж.

Ключові слова: розподільні електричні мережі, векторна оптимізація

\section{Автоматическое управление режимом электрических сетей при несимметрии напряжений}

П. Г. Плешков, В. В. Зинзура, С. П. Плешков 
Центральноукраинский национальный технический университет, г. Кропивницкий, Украина, e-mail: vasiliyzinzura@gmail.com

Цель. Повышение эффективности работы распределительных электрических сетей номинальным напряжением до 1 кВ за счет усовершенствования систем автоматического управления режимами распределительных электрических сетей с симметрокомпенсирующими устройствами в условиях несимметрии напряжений.

Методика. Методы векторной оптимизации были использованы при решении задачи автоматического управления параметрами режима распределительных электрических сетей. Методы численной оптимизации функции многих переменных были использованы для нахождения решения задачи векторной оптимизации. С помощью метода компьютерного моделирования была проведена оценка эффективности разработанной системы автоматического управления.

Результаты. Доказано преимущество предложенного метода управления режимом распределительных электрических сетей с симметрокомпенсирующими устройствами над существующими за счет учета в постановке задачи управления дополнительных критериев, а именно уровней установившегося отклонения фазных и линейных напряжений. Результаты компьютерного моделирования разработанной системы автоматического управления, в основу которой положен предложенный в работе метод, подтвердили результаты теоретических исследований: разработанная система автоматического управления, в отличии от существующих, осуществляет такие управляющие воздействия, при которых наблюдаются значения уровней несимметрии и установившихся отклонений напряжений, которые удовлетворяют нормативным требованиям относительно указанных показателей качества электроэнергии.

Научная новизна. Впервые получены решения задачи векторной оптимизации методом приближения к идеальной точке в пространстве критериев для определения алгоритма автоматического пофазного изменения реактивных сопротивлений симметрокомпенсирующих устройств, применение которых позволяет достигнуть одновременного снижения уровней потребления реактивной мощности, значений коэффициентов несимметрии по обратной и нулевой последовательностям, и значений установившихся отклонений напряжений в распределительных электрических сетях номинальным напряжением до 1 кB.

Практическая значимость. Разработанная компьютерная модель системы автоматического управления позволяет проводить исследования режимов распределительных электрических сетей номинальным напряжением до 1 кВ. Также с помощью этой компьютерной модели существенно упрощается процесс настройки микропроцессорной системы автоматического управления, в основу которой положен предложенный в работе метод автоматического управления параметрами режима распределительных электрических сетей.

Ключевые слова: распределительная электрическая сеть, векторная оптимизация

Рекомендовано до публікації докт. техн. наук В. П. Розеном. Дата надходження рукопису 12.03.18. 